\title{
Die kernbetekenis van die mens se etiese bestaanswyse
}

\author{
P.J. le Roux \\ Dept. Didaktiek \\ Universiteit van die Oranje-Vrystaat \\ BLOEMFONTEIN
}

\begin{abstract}
Ethicists differ widely in their views on the field of investigation of ethics as a science. These differences underpinning various theories regarding the true nature of ethics, seriously inhibit collaboration between adherents of different stances in this respect. Consequently meaningful progress in the development of ethical sciences can largely be attributed to divergent views on the essence (the meaning kernel or modal nucleus) of the ethical mode of human existence. In this article an attempt is made at identifying the true meaning nucleus of the ethical aspect of reality. To achieve this, the meaning of the concept meaning nucleus as well as the characteristics of meaning nuclei as such and the way in which they should be formulated, are investigated. Finally some prevailing ideas on the nature of the ethical mode of human existence are judged against the findings of this investigation.
\end{abstract}

\section{Oriënterende opmerkings}

In 'n vorige artikel "Op weg na 'n opvoedkundige etiek: problematiek rondom die terme etiek, sede en moraal" (Le Roux, 1992:87-100), is onder meer daarop gewys dat daar skerp meningsverskil bestaan aangaande wat essensieel tot die taak en terrein van die etiek behoort. Uiteenlopende essensies, oftewel sinkerne, word deur verskillende outeurs vir die etiese bestaanswyse aangedui en hierdie verskille lei tot verwarrende uitsprake met betrekking tot etiese (en vermeende etiese) aangeleenthede. 'n Aanduiding van die omvang van die probleem word soos volg deur Heyns (1980:1) geskets:

Wie die literatuur oor die etiek nagaan, kom diep onder die indruk van die wyd uiteenlopende en gevolglik verwarrende antwoorde wat gegee word op die vraag na die wese of die sinkern van die etiese. Die etiese of die sedelike bestaan - om slegs enkele, vry willekeurig-gekose voorbeelde te noem - in: menslike handelinge onder die perspektief van goed en kwaad, of onder die perspektief van die behore, of onder die perspektief van die verskillende verhoudinge, of die gemeenskap waarin die mens lewe, onder 
die perspektief van die gerigtheid op die naaste, of onder die perspektief van die navolging van Christus, die dubbele liefdesgebod, die liefdesgesindheid, gesins-, vriendskaps- en huwelikstrou, persoonsliefde, persoonsbehartiging, deugde, norme, vryheid, pligte, gedrag, karakter, lojaliteit, verantwoordelikheid, solidariteit, lewensstryd (sic), lewenstyl in die sin lewenskuns, bewustelik gemotiveerde en vir die toekoms betekenisvolle dade, waardebewussyn, waarde-oordele en die realisering van waardes, die tipies- en uniekmenslike, die behore of die normatiewe as sodanig.

Solank ernstige meningsverskil omtrent die wese, dit wil sê die diepste sin of kernbetekenis van die etiese bestaanswyse voortduur, sal vordering op die weg na 'n behoorlik gefundeerde etiek sekerlik traag verloop. Daarom sal in hierdie artikel gepoog word om deur te dring tot die sinkern van die etiese bestaansmodus, dit wil sê tot dít wat die etiese as sodanig onderskei van die res van die werklikheid om sodoende groter helderheid te verkry omtrent die aard, die taak en die terrein van die etiek as wetenskap. Aan die hand van hierdie bevindings sal enkele beskouings omtrent die wese van die etiese bestaanswyse - soos weergegee in bostaande aanhaling van Heyns - in oënskou geneem word.

\section{Die betekenis van die begrip sinkern}

Die ganse geskape werklikheid val binne die horison van sin. Buite dié horison bestaan niks buiten die Skepper wat as die Oorsprong en Bestemming van die geskapene juis sin aan die skepping verleen nie. Hierdie horison beskryf die ware aard en bestaanswyse van elke skepsel (Dooyeweerd, 1984, III:69). Dit is in beginsel dan ook nie moontlik om tot die volle waarheid omtrent die aard van enige geskapene te kom sonder om die dieper sin daarvan te verreken nie.

Alhoewel elke skepsel na sy feitlike bestaan 'n ondeelbare eenheid is, kan dit vakwetenskaplik ondersoek word alleen langs die weg van modale abstrahering (Dooyeweerd, 1975:127). Om die skepsel te kan identifiseer en uiteindelik te ken, moet daar derhalwe ondersoek ingestel word na die verskillende bestaanswyses daarvan. So 'n onderneming veronderstel uiteraard kennis aangaande die modale aspekte waarin die geskapene funksioneer.

Die modale aspekte vorm ' $n$ eenheid. Elke modale aspek bestaan slegs in samehang met al die ander aspekte (Dooyeweerd, 1984, I:3). Dit verander egter niks aan die feit dat elke aspek volgens sy eie aard geskape is nie. Hierdie stand van sake stel aan die wetenskaplike die opgaaf om as voorvraag tot sy wetenskaplike onderneming rekenskap te gee van die eie aard van elke modaliteit. Hierdie eie aard word uitgedruk in die antwoord op die vraag na die kernsin van elk van die onderskeie aspekte van die werklikheid. In hierdie opsig gaan dit om antwoorde op die vraag na die ware aard, die wese, of die sinkern van die betrokke synswyse (Dooyeweerd, 1984, I: 176). 
Om die geskikste terminologie te vind om die sinkern van 'n modale aspek so akkuraat as moontlik aan te dui, moet rekening gehou word met die onderskeid tussen ' $n$ modaliteit en ' $n$ tipiese individualiteitstruktuur wat in die modaliteit funksioneer. 'n Modaliteit dui hoedanigheid aan, terwyl 'n individualiteitstruktuur iets konkreets verteenwoordig. Daar is dan ook 'n fundamentele verskil tussen die modale hoe en die konkrete wat, wat nooit uit die oog verloor moet word nie (Dooyeweerd, 1984, II:68).

Hoewel dit nie altyd moontlik is nie, is dit gevolglik verkieslik dat vir die formulering van ' $n$ sinkern ' $n$ term gesoek word wat nie terselfdertyd ook vir iets konkreets gebruik kan word nie. Die sinkern van die ruimtelike aspek, naamlik kontinue uitgebreidheid, dui byvoorbeeld nie die ruimte aan wat ons om ons heen waarneem nie. Laasgenoemde ruimte is sensitief gekwalifiseer en funksioneer in alle aspekte (Kalsbeek, 1983:98).

Omdat die aspekte van die werklikheid dan op die hoedanigheid van dinge appelleer en nie op die konkrete wat daarvan nie, kan daar nie gevra word na die 'wat' van ' $n$ sinkern nie. So kan daar byvoorbeeld nie gevra word wat liefde (as sinkern van die etiese aspek) is nie, maar wel hoedanig hierdie liefde is.

\section{Eienskappe van sinkerne}

\subsection{Sinkerne is abstrak}

Uit wat hierbo aangemerk is, moet dit alreeds duidelik wees dat die sinkern van 'n aspek hoogs abstrak is. Sinkerne besit nie individualiteitstrukture soos dit die geval met konkrete dinge is nie. Daarom is modaliteite en hul sinkerne abstrak, terwyl die werklikheid met sy entiteite konkreet is (Smit, 1984:13). Wanneer die sinkern van ' $n$ aspek met ' $n$ naamwoord (heenwysend na iets konkreets) aangedui word, word die weg berei vir die verabsolutering van so ' $n$ modaliteit, soos byvoorbeeld gebeur het met 'die kultuur' in die geval van die historiese modaliteit en 'die lewe' in die geval van die biotiese modaliteit (vgl. Dooyeweerd, 1975:90).

\subsection{Sinkerne is ondefinieerbaar}

Om iets te definieer beteken "om in terme van die bekende, die daaromheenliggende te beskryf" (Smit, 1985:24). In die geval van 'n bestaanswyse kan die daaromheen-liggende slegs verwys na die struktuur van die bepaalde modaliteit, na dít wat juis om die sinkern heen lê. Die bekende waarvan uitgegaan word, kan dan ook niks anders as die sinkern wees nie, want slegs in terme daarvan kan die struktuur van 'n modaliteit beskryf word. 'n Sinkern is derhalwe ondefinieerbaar, want die voorvereiste is dat die sinkern eers bekend moet wees voordat daar tot definiêring oorgegaan kan word. 
It is the very nature of the modal nucleus that it cannot be defined, because every circumscription of its meaning must appeal to this central moment of the aspect-structure concerned (Dooyeweerd, 1984, II:129).

\subsection{Sinkerne is onherleibaar}

Die sinkern van 'n aspek is die uitdrukking van die unieke onherleibare eie-aard daarvan (Strauss, 1969:46). Om 'n sinkern in terme van iets anders te wil omskryf (te wil definieer), sou vereis dat dit na iets anders herlei moet word. Sodra dit gebeur, word vanselfsprekend afstand gedoen van die onherleibaarheid van die oorspronklike sinkern. In só 'n geval kan die resultaat van enige benoemingspoging nie meer beantwoord aan die aard van 'n sinkern nie. Elke poging om ' $n$ sinkern deur middel van definiëring bloot te lê, lei in der waarheid tot die teenoorgestelde, naamlik opheffing (of versluiering) van die sinkern.

\subsection{Sinkerne kan slegs in terme van ' $n$ idee benader word}

Sinkerne kan nie logies vasgepen word nie (Dooyeweerd, 1984, I:77). Omdat die bestaan van modaliteite, gekwalifiseer deur hul betrokke sinkerne, die beoefening van wetenskap voorafgaan, kan die wetenskap nie die sinkern van 'n aspek werklik in 'n greep kry nie. Gevolglik kan sinkerne nie in 'n begrip omvat word nie, maar slegs in terme van 'n idee benader word (vgl. Smit, 1985:23).

\section{Sinkern-formulering en intuïtiewe ervaring}

Dat sinkerne nie gedefinieer kan word, en bygevolg ook nie in 'n begrip vasgepen kan word nie, beteken nie dat daar nie tot kennis omtrent sinkerne gekom kan word nie. Sinkerne kan geformuleer word slegs aan die hand van intuïtiewe ervaring, met inagneming van die strukturele konteks van modale analogieë (Dooyeweerd, 1984, II:129).

Met intuïsie word bedoel "'n sekere grondliggende vermoë van die menslike normatiewe persoonlikheidstruktuur wat 'n onmiddellike skouende insig moontlik maak" (Smit, 1985:23). Intuisie verskil egter van mens tot mens en is volkome feilbaar. Daarom sal alle intuitiewe sinkern-aanduiding getoets moet word aan konkrete stande van sake in die werklikheid (Smit, 1985:73; 1984:10).

Volgens Smit (1985:23) voel almal intuïtief aan wat die etiese is en wat daartoe behoort. Hy stel dit só:

If you see love, you know love and you name it 'love'. If its (sic) there, its (sic) real. ... In the end the appeal to naive experience is the best proof of the existence of the modality of love. But it takes scientific investigation to 
formulate the meaning kernel and the interlacement relations (Smit, 1984:

14).

\section{Metode van sinkern-formulering}

Dit is reeds gestel dat die sinkern van 'n aspek langs die weg van intuitiewe ervaring gevind moet word, en nie byvoorbeeld deur 'n historiese, tematiese of etimologiese studie nie (Dooyeweerd, 1975:88). Dit is betekenisvol om daarop te let dat "'n terugval op die interpretasie van die klassieke siening van die etiek ... net so vrugteloos (is) as die etimologiese studie van èthos en éthos (waar ons woord 'etiek' sy oorsprong het)" (Smit, 1985:1). Intuitiewe waarneming moet egter nie vereenselwig word met willekeurige (emosionele) voor- of afkeure nie.

Omdat intuittiewe waarneming net so onderhewig is aan moontlike dwaling soos wetenskaplike waarneming, moet intuïtiewe waarneming ook aan dissipline onderwerp word om die potensiaal te hê om die waarheid bloot te lê. So byvoorbeeld moet die eenheidskarakter van die skepping, die enkaptiese vervlegtingsamehang van al die modaliteite en die analogiese momente wat na die sinkerne van ander modaliteite verwys, erken word (Dooyeweerd, 1975:9). Om tot 'n sinvolle antwoord op die vraag na die sinkern van 'n aspek te kom, moet daar derhalwe rekening gehou word met die modale sinverskeidenheid wat in die geskape werklikheid aanwysbaar is. In hierdie verband moet die vermeende sinkern gevolglik getoets word aan die hand van elke ander aspek, aangesien die modale sinstruktuur van elke aspek uitdrukking gee aan die volle sinsamehang van al die aspekte (vgl. Dooyeweerd, 1984, I:331). Die sinkern moet as 't ware in die struktuur van elke ander aspek pas; daarom is die kritiese metode van die antinomie (Dooyeweerd, 1984, I:48-49) 'n onontbeerlike hulpmiddel in die bepaling van 'n sinkern. Dit beteken dat toetsing van die wette van 'n modaliteit, soos hulle hulle aan die ondersoeker opdring op grond van die indentifisering van die vermeende sinkern van die modaliteit, nie die weerspreking van die wette van 'n ander modaliteit tot gevolg moet hê nie. Enige vorm van weerspreking dui op foutiewe sinkern-formulering.

\section{Identifisering van die sinkern van die etiese aspek}

'n Oorsigtelike blik op publikasies van eksponente van die reformatoriese denkrigting aangaande die sinkern van die etiese bestaanswyse bring aan die lig dat dit een van die moeilikste sinkerne is om raak te vat. Dooyeweerd (1984, II:149) praat in dié verband van die 'Cape Horn' van die filosofie - 'n beklemtoning van die besondere probleme wat die vaspenning van die sinkem van die etiese modaliteit oplewer. 
In die reformatoriese denktradisie is daar veral twee formulerings wat telkens na vore kom, naamlik liefde en trou:

\begin{abstract}
Whether one should further choose to describe the kernel as 'love' or 'troth' is a difficult question. While Dooyeweerd, Mekkes, Van Riessen and Troost choose for love in temporal relations, Vollenhoven, Popma and Taljaard prefer to speak of fidelity or troth, in marriage and friendship (Olthuis, 1969:198-199).
\end{abstract}

Olthuis"self verkies troth, terwyl Strauss (vgl. 1969:60) en Smit (vgl. 1985:30) (morele) liefde verkies.

Op die oog af wil dit tóg voorkom asof die meeste reformatoriese denkers aanvaar dat liefde die sin van die etiese aspek die beste beskryf. Dié begrip lewer egter die probleem op dat die liefde van die etiese aspek maklik verwar (en geekwivaleer) kan word met die liefde van die sentrale liefdesgebod, soos inderdaad dikwels gebeur.

An argument against choosing for 'love' as the designation (of the ethical) is the fact that one must employ the word 'love' twice. Love with a capital ' $L$ ' is used to describe the all-encompassing Total concentrated requirement of the Law in regard to mankind. Love with a small ' 1 ', as moral love, must then be seen as only one aspect of this central, radical Law of Love (Olthuis, 1969:199).

Hierbenewens is daar ook nog die verskillende konnotasies wat mense intuitief aan die begrip liefde heg - konnotasies van gevoel, huwelik en gesin, en selfs emosionele romanse (wat soms ook nog met seksuele verkeer verwar word) (vgl. Olthuis, 1969:199).

\title{
7.1 'n Fundamentele onderskeiding: die religieuse liefde van die Dekaloog
}

Om enigsins ' $n$ betroubare en toereikende idee van die sinkern van die etiese bestaanswyse te vorm, moet daar allereers ' $n$ goeie begrip wees omtrent die aard van die sentrale religieuse gebod van die liefde. So nie, sal daar weinig begrip kan wees vir die verband tussen die sinkern van die etiese modaliteit en die sentrale liefdesgebod. In hierdie opsig is daar veral twee sake waarvan deeglik kennis geneem moet word. Die eerste is die religieuse volheid van die sentrale liefdesgebod en die tweede die onverbreeklike eenheid daarvan (vgl. Strauss, 1987:41). 


\subsubsection{Die religieuse volheid van die sentrale liefdesgebod}

Met die 'religieuse volheid' van die sentrale liefdesgebod word bedoel dat dit in die ware sin van die woord allesomvattend is; dit omvat die mens se lewe integraal en radikaal.

In sy integrale omvang is die sentrale liefdesgebod gerig op die ganse lewe van die mens en is dit die wegaanduider vir elke terrein van die menslike bestaan. Enersyds is daar geen ander gebod behalwe hierdie nie en daarom bestaan die moontlikheid nie dat sekere bestaanswyses van die mens op ' $n$ ander wyse gevoed kan word nie. Andersyds is dit vanweě die onselfgenoegsame aard van die mens ook nie moontlik om sommige van sy bestaanswyses te onttrek aan die onderhoudende gebooie van God nie. Die sentrale liefdesgebod kan derhalwe nooit vereenselwig word met slegs een (of enkele) bestaanswyse(s) van die mens nie: dit omvat ál sy bestaanswyses integraal.

In sy radikaliteit lê die sentrale liefdesgebod beslag op die hart, dit wil sê die selfheid of persoonskem van die mens. In hierdie sin omvat dit die verhouding van die mens tot God - met ander woorde 'n religieuse verhouding. Nie net ten opsigte van die self nie, maar ook wat die naaste betref, is die religieuse liefdesgebod radikaal. In die sentrale liefdesgebod word aanvaar dat die naaste lid is van die radikale religieuse gemeenskap van die mensheid in sy sentrale verhouding tot God, dit wil sê as beelddraer van die Skepper. "Therefore, it is in truth the radix of all modal aspects which unfolds the divine law in temporal reality" (Dooyeweerd, 1984, I:60).

Die sentrale liefdesgebod as sodanig behoort derhalwe nie tot die modale dimensie nie, maar tot die religieuse. Dit vind wel neerslag in die modale dimensie in die vorm van trou, geregtigheid, modale liefde en so meer - hoedanighede wat as sodanig slegs modaal-tydelike sinsrefraksies van die transendentale religieuse liefdeswet is (vgl. Dooyeweerd, 1984, II:152). Dit beteken dat die sentrale liefdesgebod differensiërend tot uitdrukking kom in elkeen van die verskeidenheid lewensuitinge van die mens, en nie net in een of twee nie (Strauss, 1987:44; Troost, 1958:322). Hierdie uitvloeisel impliseer dat die sentrale liefdesgebod sy dieper sin verleen aan ál die aspekte van die werklikheid: aan die etiese - om die naaste lief te hê en hom tot diens te wees tot eer van Christus; aan die ekonomiese - om spaarsaam te werk te gaan met middele en mededeelsaam te wees ter wille van Christus se eer; aan die sosiale - om sosiaal normatief op te tree (te alle tye hoflik te wees en só my naaste lief te hê en tot diens te wees) ter wille van die eer van Christus, en so ook ten opsigte van elkeen van die ander aspekte (Smit, 1985:32). 


\subsubsection{Die onverbreeklike eenheid van die twee groot gebooie}

Die Dekaloog word in die Skrif saamgevat in "die grootste gebod" en "die tweede wat hiermee gelyk staan", soos wat in Matteus 22:40 geskryf staan: "In hierdie twee gebooie is die hele wet en die profete saamgevat." Reeds hierdie samevatting veronderstel ' $n$ eenheid.

Die sentrale liefdesgebod kan gevolglik nie dualisties verdeel word in ' $n$ sogenaamd religieuse (of godsdienstige) en 'n sogenaamd etiese deel soos Aalders en Stoker (om maar enkeles te noem) dit wil doen nie. Hulle beskou die eerste vier tafels van die Dekaloog as godsdienstig en die volgende ses as eties van aard (vgl. Strauss, 1969:353; Stoker, 1941:31, 57). Die miskenning van die eenheid van die sentrale liefdesgebod kan gewoonlik teruggevoer word na die invloed van die Skolastiek en/of verwarring omtrent die onderskeid tussen geloof en religie (vgl. Strauss, 1978:94; Dooyeweerd, 1984, II:303). Hierbo is reeds aangetoon dat geen deel van die Dekaloog op enige wyse verskraal mag word tot die etiese (of enige ander) bestaanswyse nie. Sodanige pogings lei óf tot moralisering (en/of verteologisering) van religie, of tot oplossing van die etiese (en/of die pistiese) in die religie.

In its religious fulness of meaning the love of our neighbour is nothing but the love of God in His image, expressed in ourselves as well as in our fellow-men. This is why Christ said that the second commandment is equal to the first. One can also say that it is implied in it (Dooyeweerd, 1984, II:154-155).

\subsection{Die verband tussen religieuse liefde en die sinkern van die etiese aspek}

Die liefde van die sentrale liefdesgebod is die liefde van God vir die 'wêreld' (vgl. Joh. 3:16). As sodanig is dit die liefde wat die hart van die mens opeis en op God rig. Dit is die liefde wat die mens aan die ewige God verskuldig is. Sodanige liefde is nie die liefde van die mens vir 'n aards-tydelike skepsel nie, met ander woorde nie die aards-tydelike liefde wat eie is aan een van die aspekte van die geskape werklikheid nie - dit is religieuse liefde. Daarom kan die liefde van die sentrale liefdesgebod nooit die sinkern van die etiese bestaanswyse verteenwoordig nie. Eweneens kan die religieuse liefde van die sentrale liefdesgebod ook nie opgebreek word in verskillende soorte liefde waarvan één dan as modale liefde opgeneem kan word nie.

Dit val nie vir die mens moeilik om te aanvaar dat die liefde van die eerste gebod religieuse liefde impliseer nie, dit wil sê liefde tussen God en mens. Dit word egter al té geredelik aanvaar dat die liefde van die tweede gebod dui op sogenaamd 
'horisontale' liefde tussen mens en medemens, omdat in die tweede gebod pertinent van naasteliefde gepraat word en nie van liefde tot God, soos in die eerste gebod nie. Indien die tweede gebod van die samevatting van die twee groot gebooie egter in sy verband met die tweede tafel van die Dekaloog bekyk word, behoort daar begrip te wees vir die argument dat die naasteliefde van die sentrale gebod nie die liefde (oftewel die sinkern) van een enkele modale synswyse kan wees nie; dat hierdie naasteliefde nie modale liefde kan wees nie, maar wel religieuse liefde.

Hierdie saak word in Galasiërs 5:13-14 belig: "Dien mekaar in liefde. Die hele wet word in hierdie een gebod saamgevat: 'Jy moet jou naaste liefhê soos jouself.'" Saamgelees met vers 6 verkry dit verdere helderheid: "Al wat van belang is, is geloof wat deur die liefde tot dade oorgaan." Hieruit behoort dit duidelik te wees dat dit hier om 'n allesomvattende liefde gaan en dat die naasteliefde waarvan in die sentrale religieuse liefdesgebod gepraat word, gevolglik nie tot modale liefde gereduseer mag word nie. Die liefde waarvan die Bybel hier praat, is onteenseglik religieuse liefde (vgl. Smit, 1984:7-8).

Op grond van bostaande getuienis moet aanvaar word dat daar geen unieke verband tussen die sinkem van die etiese bestaanswyse en religieuse liefde, of die sentrale liefdesgebod, is nie. Die verband hou niks méér in as dié wat religieuse liefde en die sentrale liefdesgebod met elkeen van die ander bestaanswyses het nie. Enige poging om die sinkern van die etiese modaliteit te bepaal, moet gevolglik nie afgesluit word in die sentrale liefdesgebod en religieuse liefde nie. In die sentrale liefdesgebod lê die religieuse sinvolheid van die tydelike samehang van ál die modale synswyses opgesluit (vgl. Dooyeweerd, 1984, II:146-147).

\subsection{Bybelse uitdrukkings vir liefde in Grieks}

Dit is vanselfsprekend dat daar in die Christelike etiek aandag gegee sal word aan die gebruik van die woord liefde in die Bybel, en in die besonder soos dit in die Nuwe Testament voorkom. Anders as in Afrikaans en Engels, is daar in die Griekse taal 'n verskeidenheid woorde wat liefde aandui, waarvan die belangrikste die volgende is: phileó, agapaó (en agapé), erós en stergó.

Hierdie onderskeie woorde dui verskillende soorte liefde aan. Deur hieraan aandag te gee, kan die onderskeid tussen religieuse liefde en etiese (morele) liefde enersyds bevestig word en andersyds kan dit lei tot groter helderheid omtrent die aard van etiese liefde - kan ons, met ander woorde, ' $n$ beter idee vorm van liefde as sinkem van die etiese modaliteit. 


\title{
7.3.1 Phile $\delta$ : liefde in die sin van aangetrokkenheid
}

Die woord wat in die Bybel die meeste gebruik word om liefde aan te dui, is phileó. Waar hierdie woord in die oorspronklike Griekse teks voorkom, is dit bedoel om ' $\mathrm{n}$ algemene aangetrokkenheid tot 'n persoon of ding aan te dui. Phileó word veral gebruik in die sin van liefde vir familielede en vriende, alhoewel ander mense, dinge en gode ook daardeur ingesluit kan word. Die aard van hierdie soort liefde moet gesoek word in vriendskap, gasvryheid, toewyding, geneentheid, begunstiging, tere liefde, besorgdheid (betrokkenheid), versorging en liefde vir dinge in die sin dat die mens daarvan hou. Met die oog daarop om die aard van modaal-tydelike liefde te peil, is die volgende opmerking hoogs ter sake: "Ideas related to phileó do not have a clear religious emphasis" (Brown, 1976: 538).

\subsubsection{Agapaó en agapé: vererende liefde}

Die oorspronklike betekenis van die Griekse woord agapaó (as werkwoord van die naamwoord agapé) is om te vereer of te verwelkom. In dié verband word dit soms sinoniem met phileó gebruik en dan is daar nie noodwendig ' $n$ verskil in betekenis nie. In die Nuwe Testament neem agapaólagapé egter 'n besondere betekenis aan deurdat dit gebruik word om die liefde van God, of 'n leefwyse op grond van liefde tot God aan te dui (Brown, 1976:538).

\begin{abstract}
Agapé and agapaó are used in nearly every case in the NT to speak of God's relationship with man - not unexpectedly, in view of the OT usage. Where agapé is obviously directed towards things (Lk. 11:43), the very use of the $\mathrm{vb}$. agapao is intended to make it plain that here love is directed to the wrong ends, i.e. not towards God. ... Agapé is always in the sense of ... the love of God ... i.e. God's love of men ... or ... men's love of God ... or referring to the divine love for other men which the presence of God evokes (Brown, 1976:543).
\end{abstract}

\subsubsection{Erós: 'n liefde van hartstog}

Erós is die Griekse woord wat in die Bybel gebruik word vir liefde wat begeer om te besit. Erós het die betekenis van hartstogtelike liefde, begeerte (in die sin van lus) en hunkering of smagting en word gebruik om die liefde tussen man en vrou uit te druk.

The Greeks' delight in bodily beauty and sensual desires found expression here in the Dionysiac approach to, and feeling for, life. Sensual ecstasy leaves moderation and proportion far behind, and the Gk. tragedians ... knew the irresistible power of Eros - the god of love bore the same name - 
P.J. le Roux

which forgot all reason, will and discretion on the way to ecstasy (Brown, 1976:539).

\subsubsection{Stergó: toegeneentheid}

Die Griekse woord stergó kom minder algemeen in die Bybel voor. Die betekenis daarvan is liefde en toegeneentheid veral tussen ouers en kinders. Stergó word soms ook gebruik om die liefde van 'n volk vir hul leier, die liefde van ' $n$ beskermgod(in) vir die mens, en selfs van honde vir hul meester aan te dui. Hierdie woord word egter nie in die Nuwe Testament aangetref nie, behalwe in die begrip liefdeloos in Romeine 1:31 en 2 Timoteus 3:3, en in die verbinding philostorgos (broederliefde) in Romeine 12:10 (Brown, 1976:539).

\subsection{Samevattende perspektief}

In Bybelse (en veral Nuwe-Testamentiese) sin verwys agapé (en agapaó) na 'n liefde wat nie gelyk te stel is met die liefdes van phileó, erós en stergó nie. Agapé verwys onteenseglik na 'n liefde wat die tydelike transendeer, na religieuse liefde (vgl. Dooyeweerd, 1984, II:153-154), die liefde tussen God en mens en 'n leefwyse tot eer van God op grond van hierdie liefde. Die ander soorte liefde soos uitgedruk deur die begrippe phileó, erós en stergó onderskei hulle van die religieuse liefde daarin dat hulle immanent gerig is, dit wil sê op die aards-tydelike. Hierdie liefdes vind weliswaar hulle diepste sin in die transendente, maar hul eerste uitdrukking lê op immanente vlak.

Die aard van etiese liefde moet gevolglik gesoek word in die betekenis van die Griekse begrippe phileó, erós en stergó. By wyse van samevatting kan gestel word dat die liefde wat deur hierdie terme aangedui word, verband hou met aangetrokkenheid, vriendskap, gasvryheid, toewyding, geneentheid, begunstiging, teerheid, besorgdheid, betrokkenheid, versorging, hou van, hartstog, begeerte, lus, hunkering, smagting, versugting. Kalsbeek (1983:100) noem egtelike liefde, ouer- en kinderliefde, liefde tot die vaderland en die geboorteplek, liefde tot die natuur, liefde tot bepaalde voorwerpe, waarheidsliefde, en so meer. Van Eikema Hommes (1983:492) praat van liefde "in een ruime zin" en sluit benewens bogenoemde ook in vriendskap, liefde vir die wetenskap, die solidariteit tussen lede van 'n bedryfsgemeenskap of ' $n$ universiteit, en so meer.

In die lig van die voorgaande blyk dit geregverdig te wees om die afleiding te maak dat die mens se aards-tydelike liefde nie net op die medemens gerig is nie, maar inderdaad op die ganse skepping - diere, plante en lewelose dinge ingesluit. Verder kan ook afgelei word dat (die nie-religieuse) liefde in die rigting van die transendente ontsluit moet word, anders verval dit tot iets minder as liefde - 'n blote emosie, soos ekstase. 


\section{Uitvloeisels van die modale liefdestipering van die kernsin van die etiese aspek}

Uit wat tot hiertoe bevind is omtrent die sinkern van die etiese aspek, is dit duidelik dat dit nie in die eerste plek gaan om wat die sinkern van die etiese aspek genoem word nie. Ten eerste gaan dit om wat daaronder verstaan word, met ander woorde daar moet in die eerste plek voldoende duidelikheid wees omtrent die ware aard van die etiese aspek. Daarna kan bloot gevra word watter woord (of enkele woorde) hierdie wesensaard die beste beskryf.

Om die sinkern van die etiese aspek met die woord liefde aan te dui, kan klaarblyklik nie veel fout mee gevind word nie, maar dan moet daarmee verstaan word alle modale syn wat nie onder een van die ander veertien aspekte tuishoort nie. Sodoende word die twee groot slaggate van die liefdesformulering vermy, naamlik dat die sinkern liefde nóg met die religieuse sinvolheid van die liefde, nóg met gevoel verwar mag word. Dit is waarskynlik reste van die skolastiese grondmotief wat die mens daartoe bring om in sy denke met betrekking tot die liefde te gryp na die liefde van die Bybel wat hom op religieuse liefde afstuur. Strauss (1987:39) sê onder andere:

Sodra die sentrale liefdegebod in die etiek ter sprake gebring word, wink die aanloklike gevaar van Skolastiese verskraling. Dan word maklik daaraan 'n hoëre (genade-) betekenis toegeken wat in die sentraal-religieuse aard van die liefdegebod 'n onderskeiding wil tref tussen 'n godsdienstige en ' $\mathrm{n}$ sedelike gedeelte.

Enkele ander probleme met betrekking tot die formulering van die sinkern van die etiese bestaanswyse wat na vore gekom het in die aanvanklike aanhaling van Heyns hierbo en wat moontlik nog nie voldoende behandel is nie, omvat die volgende:

Die liefde van die sinkern van die etiese aspek kan nie aangedui word as emosionele liefde nie. 'n Sinkern kan immers nie gekwalifiseer word nie, want dan het ons nie meer met ' $n$ (onherleibare) sinkern te doen nie, maar met ' $n$ analogiese moment daarvan in 'n ander werklikheidsaspek. Beklemtoning van liefde wat $g e-$ voel word, spruit waarskynlik uit vroomheid wat nie voldoende begrond is nie.

Ander pogings tot ' $n$ nadere kwalifisering skep soortgelyke probleme. Om liefde byvoorbeeld te kwalifiseer as medemenslik, sou beteken dat hierdie modaliteit (anders as enige ander modaliteit) net op die mens betrekking het. Dit sou dan inhou of dat die res van die skepping nie in hierdie modaliteit (subjektief sowel as objektief) funksioneer nie, of dat daar na 'n ander (soortgelyke) modaliteit gesoek moet word wat die res van die skepping ten opsigte van hierdie bestaanswyse sou 
kon akkommodeer. Nie een van hierdie twee opsies is egter te versoen met die reformatoriese modaliteiteleer nie.

Die poging om die res van die skepping te akkommodeer deur dit telkens op die mens se persoonlikheid te betrek, is ook nie houdbaar nie. Dit vereis eweneens 'n onaanvaarbare uniekheid met betrekking tot die etiese aspek waarvoor daar nie 'n saak uit te maak is met betrekking tot die ander aktstrukturele aspekte nie. Strauss (1969:81-82, 161-163) skryf in dié verband:

Die verskillende tydelike betrekkinge waarin die menslike liefdeslewe ingebed is, sluit óók betrekkinge met die ryk van stof, plant en dier in, en wel omdat hierdie drie natuurryke deur die mens normatief ontsluit en geobjektiveer word. ... Diereliefde, liefde vir plante (bv. blommeliefde) en liefde vir die grond (bv. vaderlandsliefde) is beslis nie liefde (behartiging) 'van persoon ván persoon' nie, maar bly nogtans struktureel deur die etiese aspek bepaal.

Troost handhaaf 'n soortgelyke siening. Hy regverdig dit deur enersyds daarop te wys dat liefde nie slegs in subjek-subjekverhoudings funksioneer nie, maar ook in subjek-objekverhoudings en andersyds deur die konkrete voorteoretiese (resp. naïewe) ervaring as toetssteen aan te lê:

In deze ervaring zien we dan bevestigd, dat ook dierenliefde, vaderlandsliefde, kunstmin, enz. niet ten onrechte als eigen-aardige liefdesrelaties worden beleefd (Troost, 1958:329).

Persoonsbehandeling, soos ook persoonsbehartiging, sluit boonop alle normatiewe handelinge in

... en kan nie bloot op grond van die sentrale liefdesgebod slegs eties wees nie. ... 'n Deegliker verrekening van die etiese as modaliteit van die normatiewe persoon van die mens sluit ' $n$ siening van die etiese as persoonsbehandeling uit. ... Kosmologies gesien is persoonsliefde te eng as norm van die etiese. ... Die Skrif het uitsprake oor dierebehandeling ook (Smit, 1985:29).

Ewemin kan die liefde van die etiese sinkern gekwalifiseer word deur tydelike betrekkinge. 'Liefde in tydelike betrekkinge' is 'n analogiese struktuurmoment van die etiese aspek - 'n retrosipasie op die sosiale aspek. Tydelike betrekkinge het as sodanig geen besondere verband met die etiese aspek nie. Daar bestaan immers ook ander tydelike betrekkinge as liefdesbetrekkinge - byvoorbeeld geloofsbetrekkinge, regsbetrekkinge, en so meer. Tydelike betrekkinge behoef derhalwe self eers 'n nadere kwalifikasie voordat 'n etiese sin daaraan toegedig kan word (Strauss, 1969:79-80).

Hoewel dit, in ooreenstemming met alle ander modale synswyses, voor die hand lê dat die etiese modaliteit nie net die eties-positiewe (die goeie) omvat nie, maar 
ook die eties-negatiewe (die slegte), moet dit tog pertinent beklemtoon word dat enige handeling teenoor enigiets wat nie getuig van liefde ten opsigte van daardie besondere iets nie, as on-eties aangemerk moet word. Omgekeerd: enige liefdelose (oftewel haatlike) handeling hoort tuis onder die etiese modaliteit omdat dit liefde misken (vgl. Kalsbeek, 1983:100). Dit kom vry algemeen voor dat iets as eties aangedui word wanneer die bedoeling is om dit as goed te beskryf. Die rede daarvoor moet dikwels ook weer gesoek word in die verwarring van modale liefde en haat met die religieuse keersye, asook die gevoelsanalogieë daarvan.

Just as in the temporal law-spheres justice and injustice, love and hatred are not internally antinomous, but only contrasts determined by the norms in the respective modalities of meaning (Dooyeweerd, 1984, II:35-36).

Ten slotte moet nog gelet word op die gebruik van die woord trou as sinkern van die etiese aspek. Soos reeds gesê, is dit nie die benaming wat deurslaggewend is in die onderhawige verband nie, maar die besondere betekenis wat daaraan geheg word. As trou die betekenis het van die verskeidenheid woorde wat hierbo gegee is om die aard van die etiese bestaanswyse aan te dui, sou dit goedskiks (soos liefde) kon deug as sinkern van die etiese aspek. Indien nie, is dit vanselfsprekend dat trou nie die ware aard van die etiese aspek voldoende beskryf nie. In sy soeke na die bestemmingsfunksie van die huwelik, is Kock (1975:139) se opmerking in hierdie verband besonder insiggewend:

Nie deur die trou nie, maar deur die liefde is die huwelik gekwalifiseer. Immers, die trou wat hier vereis word, is ten diepste liefdestrou.

Kock kwalifiseer inderdaad trou met liefde. Dit sluit aan by die gedagtes van Troost (1958:346) in hierdie verband:

Trouw is ons inziens inderdaad een concrete eigenschap of habitualiteit in een diepere laag van de actstructuur. Maar deze eigenschap kan verschillende kwalificaties aannemen; zij is $\mathrm{n}$.l. niet altijd typisch morele trouw.

In Afrikaans het ons boonop die probleem dat trou met die vertrou van die pistiese aspek verwar kan word, en ook dat die woord nie so 'n (voldoende) ryke betekenis in die volksmond het soos die woord liefde nie. Die Verklarende Handwoordeboek van die Afrikaanse Taal (Odendal, 1984:1171) bring trou byvoorbeeld slegs met die volgende in verband: dit wat beloof is, 'n verpligting, standvastig, getrou; noukeurig, stip; gehegtheid; bedoeling.

\section{Samevatting}

Die sinkern van 'n modale aspek kan nie akkuraat geformuleer word as daar nie volkome duidelikheid is omtrent die unieke betekenis daarvan nie. Teen die agtergrond van die ordelike opbou van aspekte in die werklikheid, is dit die liefde 
waarna in die Bybel verwys word as erós, stergó en phileó wat in die etiese modaliteit funksioneer. Die betekenisse van hierdie drie begrippe, soos hierbo uiteengesit, kan in geen ander aspek 'n primêre tuiste vind nie. Hierdie betekenisse belig die kernsin van die etiese aspek soos dit in sy verskeidenheid van vergestaltings gerig is op die ganse skepping tot die mate dat daar geen onduidelikheid kan wees omtrent die diepste betekenis van die etiese bestaanswyse van die mens nie.

Die woord liefde, wat die sinkern ongetwyfeld die beste beskryf, word ongelukkig dikwels verwar met religieuse liefde. Pogings om hierdie verwarring uit te skakel deur die liefde van die etiese aspek te kwalifiseer met byvoeglike naamwoorde soos morele of etiese, slaag opsigtelik nie omdat sodanige begrippe buite die konteks van die Wysbegeerte van die Wetsidee met normatiwiteit in die algemeen vereenselwig word, en nie met die normatiewe van die liefdesaspek alleen nie. Om die weg te baan vir betekenisvolle vordering in die vestiging van 'n behoorlik gefundeerde etiek sal dit goed wees as die etiese aspek anders benoem kan word (soos voorgestel in die artikel in Koers waama ten aanvang verwys is) en so ook die sinkem van die etiese aspek.

\section{Bibliografie}

BROWN, C., ed. 1976. The New International Dictionary of New Testament Theology Volume 2. Cape Town : Oxford University Press.

DOOYEWEERD, H. 1975. In the Twilight of Western Thought - Studies in the Pretended Autonomy of Philosophical Thought. Nutley, New Jersey : The Craig Press.

DOOYEWEERD, H. 1984 I. A New Critique of Theoretical Thought - The Necessary Presuppositions of Philosophy. Volume I. Ontario, Canada : Paideia Press.

DOOYEWEERD, H. 1984 II. A New Critique of Theoretical Thought - The General Theory of the Modal Spheres. Volume II. Ontario, Canada : Paideia Press.

DOOYEWEERD, H. 1984 III. A New Critique of Theoretical Thought - The Structures of Individuality of Temporal Reality. Volume III. Ontario, Canada : Paideia Press.

HEYNS, J.A. 1980. Wese van die etiese. (In Potgieter, P.C. red. Etiese probleme in Bybelse perspektief. Pretoria : N.G. Kerk Boekhandel. pp. 1-14.)

KALSBEEK, L. 1983. De Wijsbegeerte der Wetsidee - Proeve van een Christelijke filosofie Vijfde Druk. Amsterdam : Buiten \& Schipperheijn

KOCK, P. DE B. 1975. Christelike wysbegeerte - Inleiding. Bloemfontein : Sacum

LE ROUX, P.J. 1992. Op weg na 'n opvoedkundige etiek: problematiek rondom die terme etiek, sede en moraal. Koers, 57(1):87-100.

ODENDAL, F.F., red. 1984. Verklarende handwoordeboek van die Afrikaanse taal. Tweede Uitgawe, Vierde Druk. Johannesburg : Perskor.

OLTHUIS, J.H. 1969. Facts, Values and Ethics - A Confrontation with Twentieth Century British Moral Philosophy in Particular G.E. Moore. Second Edition. Assen : Van Gorcum.

SMIT, J.H. 1984. Love is Love. Reformational Forum, II (1): 7-15.

SMIT, J.H. 1985. Etos en etiek. Bloemfontein : Patmos.

STOKER, H.G. 1941. Die grond van die sedelike. Stellenbosch : Pro Ecclesia.

STRAUSS, D.F.M. 1969. Wysbegeerte en vakwetenskap. Bloemfontein : Sacum

STRAUSS, D.F.M. 1978. Inleiding tot die kosmologie. Bloemfontein : Sacum. 
Die kernbetekenis van die mens se etiese bestaanswyse

STRAUSS, D.F.M. 1987. Die etiese aspek in kosmiese samehang. Tydskrif vir Christelike Wetenskap, 23(1/2): 1-55.

TROOST, A. 1958. Casuïstiek en situatie-ethiek - Een methodologische terreinverkenning Utrecht : Libertas.

VAN EIKEMA HOMMES, H.J. 1983. De elementaire grondbegrippen der rechtswetenschap - Een juridische methodologie. Tweede Druk. Deventer : Kluwer. 